\title{
Individual Response Variations to Erythropoietin Stimulating Agents in Patients on Maintenance Hemodialysis.
}

\author{
Abdel-Hameed I.M. Ebid ${ }^{1}$, Amira M. Elsawy ${ }^{1}$, Waleed A.Taha ${ }^{2}$ \\ ${ }^{1}$ Department of Pharmacy Practice, Faculty of Pharmacy, Helwan University, Cairo, Egypt) \\ ${ }_{2}^{2}$ (Nephrology and Endocrinology Department, Maadi Military Hospital, Cairo, Egypt)
}

\begin{abstract}
:
Introduction: Erythropoietin-stimulating agents (ESA) enables the correction of anemia in patients on maintenance hemodialysis (HD) but ESA resistance remains incompletely understood among $H D$ patients.

Objectives: to examine variations in the response to erythropoietin (Epo) and identify factors which influence it. Patients and Methods: Prospective observational study conducted over 12 months on Egyptian patients on maintenance HD. The response to Epo was estimated by erythropoietin resistance index (ERI), defined as Epo dosage over a week divided by the post-HD weight and Hgb value.

Results: The study included 89 patients $(40.45 \%$ males) of avarage age 54.16 years, who had been on maintenance HD for average 94.47 months. Different ESA doses were needed to achieve and maintain the target $\mathrm{Hgb}$ range. The individual weekly dose of ESA ranged from $14.29 \mathrm{U} / \mathrm{kg} /$ week to $196.96 \mathrm{U} / \mathrm{kg} /$ week and of the ERI ranged from $1.22 \mathrm{U} / \mathrm{kg} / \mathrm{week} / \mathrm{g} / \mathrm{dl}$ to $17.13 \mathrm{U} / \mathrm{kg} / \mathrm{week} / \mathrm{g} / \mathrm{dl}$. A satisfactory Epo response with ERI below $5 \mathrm{U} / \mathrm{kg} / \mathrm{week} / \mathrm{g} / \mathrm{dl}$ was found in $33.7 \%$ of patients, while $23.6 \%$ had average ERI above the $10 \mathrm{U} / \mathrm{kg} / \mathrm{week} / \mathrm{g} / \mathrm{dl}$, indicating that the percentage of patients with a poor response to Epo is not negligible. Multivariate analysis revealed serum albumin, transferrin saturation and statins use to be inversely related to ERI, whereas $C$ reactive protein $(C R P)$, dialysis dose $(\mathrm{spKt} / \mathrm{V})$, angiotensin-converting enzyme inhibitor(ACEI)/ angiotensin receptor blocker(ARB) use and intact parathyroid hormone (iPTH) were associated with higher ESA resistance. Conclusion: Target Hgb levels were achieved and maintained by different doses of Epo in individual patients as a result of large individual variations in the response to ESA estimated by the ERI. Serum albumin and CRP were the strongest independent predictors of ERI.
\end{abstract}

Keywords: Hemodialysis, Renal anemia, Erythropoietin resistance, Erythropoietin stimulating agents.

\section{Introduction}

Deficiency of Erythropoietin (Epo) production by the kidney is the primary cause of anemia in patients with end-stage renal disease (ESRD) [1]. Discovery of erythropoietin-stimulating agents (ESAs) has revolutionized anemia management in ESRD patients by improvement quality of life and reduction of transfusions in these patients [2].

According to KDOQI Clinical Practice Guideline for Anemia in Chronic Kidney Disease (CKD) and KDIGO Clinical Practice Guideline for Anemia in Chronic Kidney Disease, the target hemoglobin (Hgb) level to be achieved is $11-12 \mathrm{~g} / \mathrm{dl}$ and 11 to $12.5 \mathrm{~g} / \mathrm{dl}$, respectively [3,4]. However, clinical experience has shown that achieving and maintaining the target range of Hgb is not easy. Although, the response to treatment with ESA is dose dependent in most patients [5-7], the response may vary widely over time between patients and even within a given individual. Individual patients showed significant variations in the concentration of Hgb over time and only a small percentage of patients maintained stable target Hgb level[8-11]. Fluctuations in Hgb levels are very common, and different studies have explored $\mathrm{Hgb}$ variability and $\mathrm{Hgb}$ cycling phenomenon in individual patients $[8,12]$.

ESA resistance and therefore the need for higher doses of ESA is a common problem affecting 5-10\% of hemodialysis (HD) patients[5]. Several studies reported the association of Epo dosage and responsiveness with mortality[13-17].

Main factors associated with ESA resistance include iron deficiency [18] low serum albumin level [19], malnutrition [20], hyperparathyroidism[21], suboptimal dialysis[22]; however, ESA resistance is still an incompletely understood problem. Therefore, identifying the factors that associate with ESA resistance is important not only in reducing the costs associated with the treatment, but also possibly in influencing patients' mortality risks.

The aim of this study was to investigate the prevalence of insufficient response to treatment with ESA and to identify and quantify factors that influence ESA resistance in the ESRD patients on maintenance HD. 


\subsection{Patients}

\section{Patients And Method}

The study subjects were recruited from outpatients who received HD for 3.5 to 4 hours three times weekly in the dialysis units in the Nephrology Hospital of the Armed Forces Medical Center at Maadi; Cairo, Egypt. All patients received conventional HD with bicarbonate as a dialysate.

Patients were eligible for the study if they fulfilled the following criteria; aged $\geq 18$ years, on stable HD for at least 3 months or longer, and who subjected to an ESA treatment. Eligible patients agreed to sign an informed consent were followed prospectively for 12 months from February 01, 2015 to January 31, 2016. The patients were excluded for one or more of the following criteria: (1) had active or recent neoplasia, (2) received red blood cells (RBCs) transfusion one month before the start or during study period, (3) had major surgical surgery or bleeding one month before the start or during study period, and (4) failed to be followed during one year study period either due to death, discontinuation of HD or transfer out of the unit.

The study protocol was approved by the research and ethics committee of the Faculty of Pharmacy, Helwan University and the Ethical Committee of the Nephrology Hospital of the Armed Forces Medical Center at Cairo, Egypt.

\subsection{Anemia Management}

All patients received ESA treatment according to routine clinical practices in the unit which followed the standard guidelines at the time of the study[3]. According to the hospital suppliers, Epoetin alfa (Eprex ${ }^{\circledR}$ $4000 \mathrm{IU}$ ), Epoetin beta (NeoRecormon ${ }^{\circledR} 5000 \mathrm{IU}$ ) and darbepoetin alfa (Aranesp® 20, 30 and $60 \mu \mathrm{g}$ ) were the available ESA during one year study period. The dose was monthly determined on the basis of the target $\mathrm{Hgb}$ level that amounted to 10-12 g/dl. Patients received Epo subcutaneously or intravenously at the end of the HD section. A dose conversion ratio of 1:200 was used to convert darbepoetin to that of epoetin (1 mg of darbepoetin alfa=200 IU of epoetin alfa or beta) [23,24]. Intravenous iron sucrose (Ferosac $($ ) was given to achieve serum ferritin levels between 200 - $500 \mathrm{mg} / \mathrm{l}$ and individualized based on the patient's Hgb concentration at the physician's clinical discretion. Iron therapy was interrupted when serum ferritin levels exceeded $800 \mathrm{mg} / \mathrm{l}$.

\subsection{Data Collection and Blood Sampling}

Data on demographic characteristics (gender and age), pre and post dialysis body weight, height, etiology of chronic kidney disease (CKD), dialysis duration, vascular access, co-medications and various comorbidities were recorded at the start of the study. During the follow up period, data pertinent to treatment of anemia including ESA type and dose, iron doses and blood transfusion administration, were monthly collected. Patients' adequacy of dialysis dose measured by single pool Kt/V (spKt/V) was monthly calculated according to the second-generation equation of Daugirdas [25].

Blood was drawn in the third week of each month, after an overnight fast, before the start of the HD session. Patients' blood samples were taken for laboratory analyses. Complete blood count, serum albumin, iron, calcium, inorganic phosphorus, alkaline phosphatise (ALP) and lipid profile (total cholesterol and triglyceride) were measured at monthly intervals for one year duration, while serum ferritin and intact parathyroid hormone (iPTH) and anti-hepatitis C virus (HCV) antibodies were performed on quarterly basis in February, May, August and November 2015. Total iron binding capacity (TIBC) and high sensitivity C-reactive protein (CRP) were determined semi-annually in February and August as they were not routinely measured. CRP was determined by an immunoturbidimetric method (a reference value $0-5 \mathrm{mg} / \mathrm{l}$ ). Laboratory analyses were measured according to widely used techniques.

\subsection{Statistical Analysis}

The outcome measure used to evaluate the dose-response effect of ESA treatment was the erythropoietin resistance index (ERI) defined as total Epo dosage over a week divided by the average post HD weight for that week, further divided by the most recent Hgb concentration [26,27] to normalize the amount of required ESA for the degree of severity of anemia. Results are presented as means \pm standard deviations (SD) and range for continuous variables. Categorical data are presented as frequencies and percentages.

Pearson correlation test was used to determine relationship between parametric continuous variable and ERI, while correlations between nonparametric continuous variables were calculated as the spearman's rho coefficient. Further analysis included a univariate analysis to compare ERI values among categories of patients' characteristics. Categorical variables were compared with the Mann-Whitney U-test and continuous variables were compared with Student's t-test, the Mann-Whitney U-test and analysis of variance (ANOVA) test.

Multiple linear regression modeling was performed to determine independent predictors of ERI and the variance in ERI that is accounted for by these variables. All variables directly included in the ERI definition (i.e. ESA doses, Hgb values and measures of body mass index (BMI)) were excluded of the regression model in 
order to minimize collinearity. A $P$ value less than or equal to 0.05 was considered statistically significant. All statistical analyses were performed with SPSS V. 22.

\section{Results}

A total of 101 patients were identified by inclusion criteria but 12 were missed during the 12 months follow up period because 7 were died, 2 had blood transfusion, and 3 were transferred out of unit. Therefore, data from 89 patients were available for study analysis. Baseline demographics and clinical characteristics of the studied patients were described in Table1.

Table1: Baseline demographics and clinical characteristics of the studied patients.

\begin{tabular}{|c|c|c|}
\hline \multicolumn{2}{|c|}{ Characteristic } & $\begin{array}{c}\text { Population study } \\
\text { Mean } \pm \text { SD or } n(\%)\end{array}$ \\
\hline \multicolumn{2}{|c|}{ Number of patient (n) } & 89 \\
\hline \multicolumn{2}{|c|}{ Gender (Male) } & $36(40.45)$ \\
\hline \multicolumn{2}{|c|}{ Age (years) } & $54.16 \pm 15.68$ \\
\hline \multicolumn{2}{|c|}{ Baseline Body Weight (kg) } & $76.05 \pm 19.37$ \\
\hline \multicolumn{2}{|c|}{$\mathrm{Ht}(\mathrm{cm})$} & $164.25 \pm 10.22$ \\
\hline \multicolumn{2}{|c|}{$\mathrm{BMI}\left(\mathrm{kg} / \mathrm{m}^{2}\right)$} & $28.16 \pm 7.08$ \\
\hline \multicolumn{2}{|c|}{ Time on HD (Months) } & $94.47 \pm 76.71$ \\
\hline \multicolumn{2}{|c|}{ Baseline spKt/V } & $1.16 \pm 0.37$ \\
\hline \multirow{7}{*}{ Etiology of CKD } & Hypertension & $35(39.33)$ \\
\hline & Diabetes mellitus & $11(12.36)$ \\
\hline & Chronic interstitial nephritis & $12(13.48)$ \\
\hline & Polycystic kidney & $8(8.99)$ \\
\hline & Glomerular disease & $4(4.49)$ \\
\hline & Others & $17(19.10)$ \\
\hline & Unknown & $2(2.25)$ \\
\hline \multirow{3}{*}{ Vascular access } & AV Fistula & $81(91.01)$ \\
\hline & Permanent catheter & $3(3.37)$ \\
\hline & Synthetic graft & $5(5.62)$ \\
\hline \multirow{2}{*}{ Dialyzers' membrane } & Low flux (FX 10) & $27(30.34)$ \\
\hline & High flux (F70S) & $62(69.66)$ \\
\hline \multirow{5}{*}{ Co-morbidity factor } & Arterial hypertension & $62(69.66)$ \\
\hline & Diabetes mellitus & $20(22.47)$ \\
\hline & Congestive heart failure & $14 / 15.73$ \\
\hline & Ischemic heart disease & $6(6.74)$ \\
\hline & Positive HCV Abs & $50(57.47)$ \\
\hline \multicolumn{2}{|c|}{ Plan for transplantation } & $10(11.24)$ \\
\hline \multicolumn{2}{|c|}{ Previous failed transplantation } & $9(10.11)$ \\
\hline \multicolumn{2}{|c|}{ ACEI/ARBs use } & $19(42.22)$ \\
\hline \multicolumn{2}{|c|}{ Statin use } & $14(15.73)$ \\
\hline
\end{tabular}

CKD: chronic kidney disease, spKt/V: single-pool Kt/V (index of adequacy of dialysis dose), $\boldsymbol{A} \boldsymbol{V}$ : arteriovenous, FX 10, Fresenius Helixone ${ }^{\circledR}$ low-flux dialysis membrane, F70S: Fresenius Polysulfone ${ }^{\circledR}$ High-Flux dialysis membrane. HCV Abs: Hepatitis $C$ virus antibodies, ACEI: angiotensin converting enzyme inhibitor, ARB: angiotensin II receptor blocker.

Average laboratory parameters measured during one year follow up are presented in Table 2. The arithmetic mean concentration of the measured laboratory parameters were within their normal limits. It is evident that the values of iPTH were elevated. The concentrations of serum iron and serum ferritin, as well as the transferrin saturation were in the recommended intervals.

All patients achieved the target Hgb level 10-12 g/dl except 3 patients whose 12 values of $\mathrm{Hgb}$ concentration recorded in the 12 follow-up months were below10 g/dl. The distribution of patients according to the average concentration of $\mathrm{Hgb}$ for the whole year and the number of patients in whom the Hgb concentration at least once during the year was below $10 \mathrm{~g} / \mathrm{dl}$ was represented in Fig. 1. Although the average concentration of $\mathrm{Hgb}$ was above $10 \mathrm{~g} / \mathrm{dl}$ in 73 of 89 patients (about $82 \%$ ), in 44 patients during one year, this concentration was one to 9 times was lower than $10 \mathrm{~g} / \mathrm{dl}$. As expected, this low Hgb more often occurred in patients with an average $\mathrm{Hgb}$ concentration of less than $11 \mathrm{~g} / \mathrm{dl}$. In 19 patients $(21.35 \%) \mathrm{Hgb}$ concentration below $10 \mathrm{~g} / \mathrm{dl}$ was recorded three times or more during one year study period and they were patients who may be considered as patients with a weak response to Epo. 
Table 2: Laboratory parameters measured during one-year follow up

\begin{tabular}{|c|c|}
\hline Laboratory parameters For the whole year & mean \pm SD (range) \\
\hline Hemoglobin, $\mathrm{g} / \mathrm{dl}$ & $10.77 \pm 1.12(8.73-12.45)$ \\
\hline Hematocrite, $\%$ & $33.46 \pm 2.90(23.3-38.9)$ \\
\hline Blood Urea (Predialysis), mg/dl & $135.88 \pm 23.74(90.43-225.58)$ \\
\hline Blood Urea (Postdialysis), mg/dl & $52.32 \pm 12.56(31.1-89.91)$ \\
\hline Creatinine (Predialysis), mg/dl & $10.43 \pm 2.41(4.93-18.61)$ \\
\hline Creatinine (Postdialysis), mg/dl & $4.36 \pm 1.49(2.43-13.25)$ \\
\hline spKt/ $/ 1.19 \pm 0.37(0.7-1.9)$ \\
\hline Calcium, mg/dl & $8.35 \pm 0.94(6.65-9.78)$ \\
\hline Phosphorus, mg/dl & $4.69 \pm 1.32(2.62-7.77)$ \\
\hline ALP, U/l & $215.48 \pm 245.69(39.43-1407.9)$ \\
\hline Albumin, $\mathrm{g} / \mathrm{dl}$ & $3.98 \pm 0.48(3.42-4.68)$ \\
\hline Total Cholesterol, mg/dl & $170.55 \pm 43.26(81.75-267.2)$ \\
\hline Triglycerides, $\mathrm{mg} / \mathrm{dl}$ & $157.76 \pm 78.77(56.33-416.92)$ \\
\hline CRP, $\mathrm{mg} / \mathrm{l}$ & $12.33 \pm 9.15(0.60-27.6)$ \\
\hline Serum Iron, $\mu \mathrm{g} / \mathrm{dl}$ & $74.95 \pm 26.43(47.37-164.21)$ \\
\hline TIBC, $\mu \mathrm{g} / \mathrm{dl}$ & $261.34 \pm 61.93(146.50-441)$ \\
\hline Transferrin Saturation, $\%$ & $31.94 \pm 12.66(10.54-89.80)$ \\
\hline Ferritin, $\mathrm{ng} / \mathrm{ml}$ & $426.90 \pm 358.80(17.70-1445.35)$ \\
\hline iPTH, $\mathrm{pg} / \mathrm{ml}$ & $571.31 \pm 446.81(1.60-1706.55)$ \\
\hline
\end{tabular}

SD: standard deviation, spKt/V: single-pool Kt/V (index of adequacy of dialysis), ALP: alkaline phosphatise, CRP

$C$ - reactive protein, TIBC: total iron binding capacity, $\mathbf{P P T H}$ : intact-parathyriod hormone

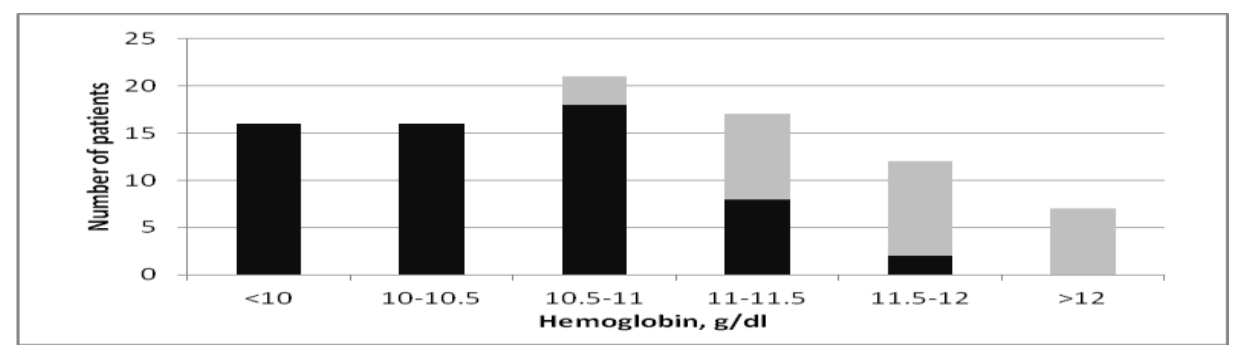

Figure 1: Distribution of patients according to the mean concentration of hemoglobin for the whole year. The darker part of columns represented no. of patients with at least one $\mathrm{Hg}$ concentration value below $10 \mathrm{~g} / \mathrm{dl}$.

Table 3 showed the average concentrations of the Hgb level, weekly dose of Epo per $\mathrm{kg}$ of body weight, iron doses and ERI first months of each calendar quarter during one year follow up, and for the whole year. The scope of individual values of $\mathrm{Hgb}$ and the average doses of Epo showed individual differences between months. There were great variation in Epo doses; however, Hgb values remained in their target level. This was due to continuous Epo dosage adjustment to maintain the Hgb target.

Table 3: Hgb level, weekly doses of Epo, ERI and intravenous iron doses in first months of each calendar quarter during one year follow up and for the whole year.

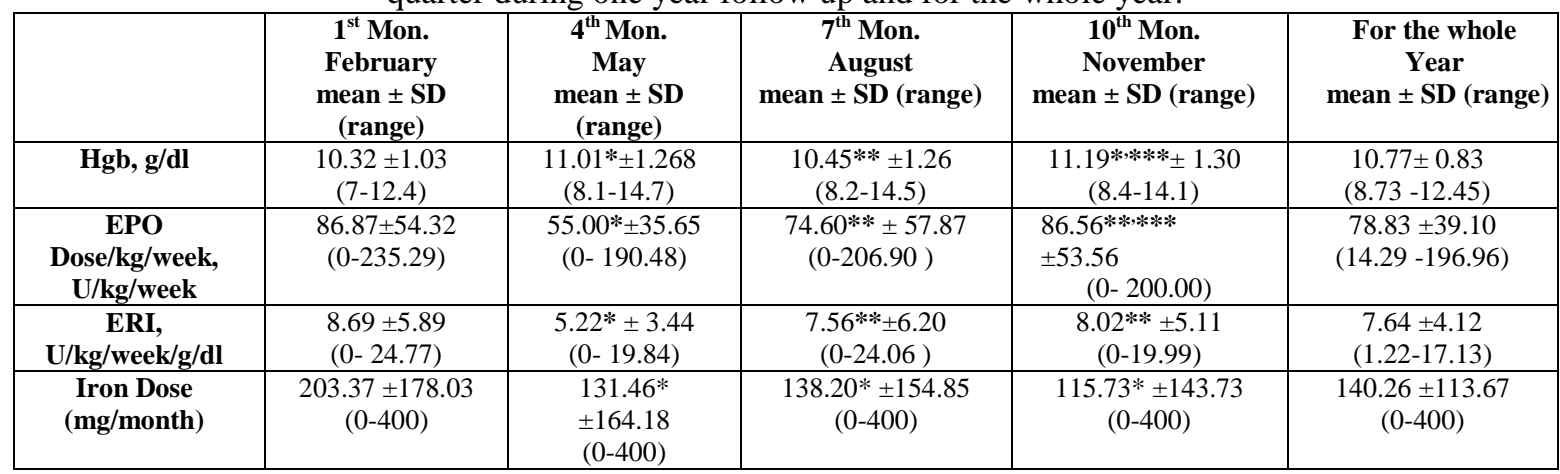

$* P<0.05$ compared to the value in February, $* * P<0.05$ compared to the value in May, $* * * P<0.05$ compared to the value in August

Out of 89 studied patients, 86 patients (96.6\%) achieved the target concentration Hgb 10-12 g/dl but the average weekly Epo doses for individual patients showed great variation, and were ranged from 14.29 to $196.96 \mathrm{U} / \mathrm{kg} /$ week. Analysis of individual ERI values showed large differences in index values between individual patients. The lowest value of individual ERI was zero indicated suppression of Epo dose in that month, and even the highest value of individual ERI was $25.54 \mathrm{U} / \mathrm{kg} / \mathrm{week} / \mathrm{g} / \mathrm{dl}$. Mean ERI for the entire studied patients was $7.64 \mathrm{U} / \mathrm{kg} / \mathrm{week} / \mathrm{g} / \mathrm{dl}$. It turned that is the lowest individual average ERI value was 1.22 
$\mathrm{U} / \mathrm{kg} / \mathrm{week} / \mathrm{g} / \mathrm{dl}$, and the highest average was $17.13 \mathrm{U} / \mathrm{kg} /$ week $/ \mathrm{g} / \mathrm{dl}$. The calculated mean value of ERI for each patient was on the basis of 12 values received during the 12 months observed. Distribution of patients according to the mean value of ERI is shown in Fig. 2. Thirty (33.7\%) patients had average ERI below $5 \mathrm{U} / \mathrm{kg} / \mathrm{week} / \mathrm{g} / \mathrm{dl}$. Forty two (47.19\%) patients had average ERI above $7 \mathrm{U} / \mathrm{kg} / \mathrm{week} / \mathrm{g} / \mathrm{dl}$, and even half of them $(23.6 \%)$ had average ERI above the $10 \mathrm{U} / \mathrm{kg} / \mathrm{week} / \mathrm{g} / \mathrm{dl}$, indicating that the percentage of patients with a poor response to Epo is not negligible.

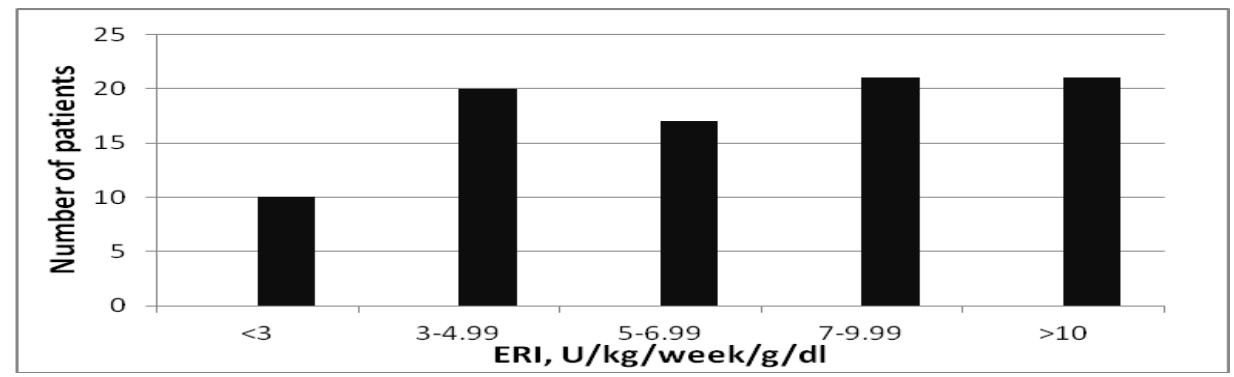

Figure 2: Distribution of patients according to the mean value of erythropoietin resistance index (ERI) calculated from 12 values recorded in the 12 follow-up months.

As expected, the weekly weight-adjusted dose of Epo (U/week/kg) was inversely related to $\mathrm{Hgb}$ concentration $(\mathrm{r}=-0.630, P<0.001)$ and directly associated with ERI $(\mathrm{r}=0.993, P<0.001)$. Correlation analysis, as expected also, showed that there is a strong association between ERI and Hgb concentration $(\mathrm{r}=-$ 0.694; $P<0.001)$. Males had a significantly lower ERI $(6.47 \pm 3.73 \mathrm{U} / \mathrm{week} / \mathrm{kg} / \mathrm{g} / \mathrm{dl})$ than females $(8.44 \pm 4.22$ $\mathrm{U} / \mathrm{week} / \mathrm{kg} / \mathrm{g} / \mathrm{dl}$, P value was $<0.05)$. There was an inverse correlation between age and ERI, older age was associated with lower ERI in the studied patients $(\mathrm{r}=-0.229, P<0.05)$. Sixty years old and older patients had a significantly lower ERI compared with younger ones $(P<0.05)$, the mean ERI in older patients ( $>60$ years) was $6.72 \pm 3.66$ while it was $8.59 \pm 4.39$ in younger ones ( $\leq 60$ years). Increased BMI was associated with a significantly lower ERI values $(\mathrm{r}=-0.282, P=0.007)$. The mean ERI in overweighed patients $(\mathrm{BMI}>25 \mathrm{Kg} / \mathrm{m} 2)$ was $6.67 \pm 3.80$ significantly lower than that in patients with $\mathrm{BMI} \leq 25 \mathrm{Kg} / \mathrm{m} 2$ which was $9.44 \pm 5.11(P=0.008)$.

There were no significant differences in ERI associated with the causes of CKD $(\mathrm{f}=0.437, P>0.05)$ or with months on HD $(\mathrm{r}=-0.109, P>0.05)$. In contrast, there was a significant increase in ERI as a result of increased dialysis dose $(\mathrm{spKt} / \mathrm{V})$ in the studied patients $(\mathrm{r}=0.328, P=0.002)$. In patients on dialysis with lowpermeability membranes (Low flux, FX10), ERI was almost similar to that in patients with higher membrane permeability (High flux, F70S) $(7.63 \pm 3.52 \mathrm{vs} 7.65 \pm 4.38 \mathrm{U} / \mathrm{kg} / \mathrm{week} / \mathrm{g} / \mathrm{dl}, P>0.05)$. ERI was slightly higher in patients who planned for transplantation than patients didn't, although the difference was not statistically significant $(9.01 \pm 3.76$ vs $7.47 \pm 4.16 \mathrm{U} / \mathrm{kg} / \mathrm{week} / \mathrm{g} / \mathrm{dl}, P>0.05)$.

There were no significant differences in ERI between patients with and without hypertension, nor were there significant differences in ERI associated with the presence of diabetes mellitus or congestive heart failure. Results revealed that ERI values of anti-HCV-positive patients were lower than those of anti-HCV-negative ones; however, the difference wasn't statistically significant $(7.20 \pm 4.36$ vs $8.25 \pm 3.84 \mathrm{U} / \mathrm{kg} / \mathrm{week} / \mathrm{g} / \mathrm{dl}, P>$ 0.05). ACEI/ARB use was associated with significant higher ERI than non use $(9.52 \pm 3.85$ vs $7.13 \pm 4.07$ $\mathrm{U} / \mathrm{kg} / \mathrm{week} / \mathrm{g} / \mathrm{dl}, P=0.018)$. In contrast, statins use was associated with significant lower ERI than non use (5.35 \pm 3.34 vs $8.07 \pm 4.13 \mathrm{U} / \mathrm{kg} / \mathrm{week} / \mathrm{g} / \mathrm{dl}, P=0.025)$.

ERI had significant negative correlation with serum albumin levels $(\mathrm{r}=-0.412, P<0.001)$, patients with serum albumin concentrations $>4 \mathrm{~g} / \mathrm{dl}$ had a significantly lower ERI values $(6.18 \pm 3.06 \mathrm{U} / \mathrm{kg} / \mathrm{week} / \mathrm{g} / \mathrm{dl})$ than ones with serum albumin concentrations $\leq 4 \mathrm{~g} / \mathrm{dl}(9.01 \pm 4.53 \mathrm{U} / \mathrm{kg} / \mathrm{week} / \mathrm{g} / \mathrm{dl}, P<0.001)$. There was a significant direct correlation between CRP concentrations and ERI $(\mathrm{r}=0.304, P=0.004)$.

Transferrin saturation correlated inversely with ERI $(r=-0.265, P=0.012)$. For the 12 patients with transferrin saturation $<20 \%$, mean ERI was $10.90 \pm 3.69$; for the 59 patients with transferrin saturation $20 \%-$ $40 \%$, ERI was $7.34 \pm 4.15$; and for the 18 patients with transferrin saturation $>40 \%$, ERI was $6.46 \pm 3.33$ $\mathrm{U} / \mathrm{kg} / \mathrm{week} / \mathrm{g} / \mathrm{dl}(P=0.008)$. In contrast, results revealed no significant correlation between ferritin levels and ERI $(\mathrm{r}=-0.041, P>0.05)$. Furthermore, there were no significant differences in ERI between patients whose ferritin levels were above $100 \mathrm{mg} / \mathrm{l}(\mathrm{n}=46,51.69 \%)$ compared with whom levels were below $100 \mathrm{mg} / \mathrm{l}(7.72 \pm$ 4.14 vs $7.38 \pm 4.16 \mathrm{U} / \mathrm{kg} / \mathrm{week} / \mathrm{g} / \mathrm{dl}, P>0.05$ ). There was a significant positive correlation between iPTH and ERI $(\mathrm{r}=0.274, P=0.009)$. In contrast, ERI had no significant correlation with serum iron $(\mathrm{r}=-0.139, P>0.05)$, iron dose $(\mathrm{r}=0.173, P \mathrm{P}>0.05)$, TIBC levels $(\mathrm{r}=0.123, P>0.05)$, ALP $(\mathrm{r}=-0.026, P>0.05)$, calcium $(\mathrm{r}=-$ $0.142, P>0.05)$ or with phosphorus $(\mathrm{r}=-0.063, \mathrm{P}>0.05)$. Results also revealed that iPTH was statistically significantly correlated with the ERI $(\mathrm{r}=0.274, P=0.008)$. 
In respect to lipid profile, ERI had no significant correlation with total cholesterol $(\mathrm{r}=-0.034, \mathrm{P}>0.05)$ or with triglycerides $(\mathrm{r}=-0.153, P>0.05)$. Sixty eight patients $(76.40 \%)$ were with cholesterol levels $<200$ $\mathrm{mg} / \mathrm{dl}$. The mean ERI for those patients was $7.63 \pm 4.39 \mathrm{U} / \mathrm{kg} /$ week/g/dl; in the 19 patients whose cholesterol levels were between $200 \mathrm{mg} / \mathrm{dl}$ and $240 \mathrm{mg} / \mathrm{dl}$, ERI was $7.98 \pm 3.22 \mathrm{U} / \mathrm{kg} / \mathrm{week} / \mathrm{g} / \mathrm{dl}$. In 2 patients with cholesterols $>240 \mathrm{mg} / \mathrm{dl}$, ERI was $5.01 \pm 0.79$ lower than the other groups. However, the difference wasn't statistical significant $(P>0.05)$.

Multiple linear regression modeling was performed to determine independent predictors of ERI. The basic multivariate model was created by incorporating all predictors with a $P$ value $<0.1$ in correlation analysis. Therefore, influence of gender, age, statins use, ACEI/ARBs use, spKt/V, serum albumin, CRP, iPTH and transferrin saturation were tested by enter method in SPSS. Table 4 showed regression coefficients for variables predicting ERI in the basic multivariate model. R squared was $49.4 \%(P<0.001)$.

Backward regression procedure was then performed. Non significant terms $(\mathrm{P}>0.05)$ were removed from the analysis and only variables which led to a significant contribution were retained to develop the next model of ERI. Regression coefficients for variables predicting ERI in the final model is showed in table 5. Table 5 showed that $47.7 \%$ of the variance in the ERI was explained by the following variables: serum albumin, CRP, iPTH, transferrin saturation, spKt/V, statins use and ACEI/ARBs use. Serum albumin was the strongest independent predictor of ERI. CRP was the second strongest significant factor associated with ERI.

Table 4: Basic multivariate model for variables predicting ERI.

\begin{tabular}{|c|c|c|c|c|c|c|}
\hline & \multicolumn{2}{|c|}{$\begin{array}{c}\text { Unstandardized } \\
\text { Coefficients }\end{array}$} & \multicolumn{2}{c|}{$\begin{array}{c}\text { Standardized } \\
\text { Coefficients }\end{array}$} & \multicolumn{3}{c|}{$\begin{array}{c}\text { 95\% Confidence } \\
\text { Interval for B }\end{array}$} \\
\cline { 2 - 7 } & Beta & SE & Beta & $\begin{array}{c}\text { Lower } \\
\text { Bpper } \\
\text { Bound }\end{array}$ \\
\hline (Constant) & 30.867 & 9.302 & & 0.001 & 12.353 & 49.382 \\
\hline Gender & 1.057 & 0.687 & 0.127 & 0.128 & -0.311 & 2.425 \\
\hline log Age & -1.819 & 2.965 & -0.062 & 0.541 & -7.721 & 4.082 \\
\hline SpKt/V & 3.144 & 1.860 & 0.176 & 0.095 & -0.557 & 6.845 \\
\hline Statin use & -2.228 & 0.925 & -0.198 & 0.018 & -4.068 & -0.388 \\
\hline ACEI/ARBs use & 1.753 & 0.825 & 0.175 & 0.037 & 0.110 & 3.395 \\
\hline Albumin & -4.798 & 1.505 & -0.279 & 0.002 & -7.793 & -1.803 \\
\hline CRP & 0.103 & 0.038 & 0.229 & 0.009 & 0.027 & 0.179 \\
\hline log TSAT & -5.199 & 2.141 & -0.212 & 0.017 & -9.460 & -0.938 \\
\hline iPTH & 0.002 & 0.001 & 0.188 & 0.028 & 0.000 & 0.003 \\
\hline
\end{tabular}

SE: standard error, Sig.: Significance P value, CRP: C-reactive protein, spKt/V: single-pool Kt/V (index of adequacy of dialysis), iPTH: intact-parathyriod hormone, TSAT: Transferrin saturation, ACEI: angiotensin converting enzyme inhibitor, ARB: angiotensin II receptor blocker, log: logarithm.

Table 4.24: Final multivariate model for variables predicting ERI.

\begin{tabular}{|c|c|c|c|c|c|c|}
\hline & \multicolumn{2}{|c|}{$\begin{array}{c}\text { Unstandardized } \\
\text { Coefficients }\end{array}$} & \multicolumn{2}{c|}{$\begin{array}{c}\text { Standardized } \\
\text { Coefficients }\end{array}$} & $\begin{array}{c}\text { 95\% Confidence Interval } \\
\text { for B }\end{array}$ \\
\cline { 2 - 7 } & Beta & SE & Beta & Sig. & Lower Bound \\
Bound
\end{tabular}

SE: standard error, Sig.: Significance P value, CRP: $C$ - reactive protein, $\mathbf{s p K t / V}$ : single-pool Kt/V (index of adequacy of dialysis), TSAT: Transferrin saturation, iPTH: intact-parathyriod hormone, ACEI: angiotensin converting enzyme inhibitor, ARB: angiotensin II receptor blocker.

\section{Discussion}

This study has analyzed the response to ESA and reported the association between demographics, laboratory parameters, medication use, co-morbidity factors and ESA resistance in a sample of relatively stable patients undergoing chronic HD that were followed for a period of 1 year. Response to treatment with Epo and variations in this response were assessed in this study using ERI which defines the relationship between body weight-adjusted dose of Epo and $\mathrm{Hgb}$ concentration. The major finding of this study is that serum albumin, $\mathrm{CRP}$, iPTH, transferrin saturation, spKt/V, statins and ACEI/ARBs medications are independently associated with ESA resistance and serum albumin and CRP were the strongest independent predictors of ERI.

It is very important to maintain target $\mathrm{Hgb}$ level because maintaining of $\mathrm{Hgb}$ concentration at less than $10 \mathrm{~g} / \mathrm{dl}$ as well as frequent variations with occasionally falling of $\mathrm{Hgb}$ concentration below $10 \mathrm{~g} / \mathrm{dl}$ are 
associated with an increased risk of mortality and have a negative impact on the quality of life[16,28-31]. On the other hand, attempts to raise Hgb target showed that the increase Hgb level over $13 \mathrm{~g} / \mathrm{dl}$ is also related to higher mortality rate and doesn't associate with a significant reduction of cardiovascular events [17,29,32-34]. Furthermore, previous studies have shown that the variation of the Hgb over time associated with mortality risks, more frequent comorbidities and hospitalizations [8,9,34,35]. In the current study, the average $\mathrm{Hgb}$ concentration of each month of total 12 months observed ranged between 10.32 and $11.19 \mathrm{~g} / \mathrm{dl}$ which maintained between 10-12 g/dl. Throughout the year, the average Hgb concentration for the whole sample was $10.77 \mathrm{~g} / \mathrm{dl}$. This was in accordance with FDA recommendations that warned risks for death, serious adverse cardiovascular reactions, and stroke when administered ESAs to target a Hgb level of greater than $11 \mathrm{~g} / \mathrm{dl}$ [36].

Special attention is paid to research of insufficient response the treatment of Epo and to causes of the inadequate response [37-41] because of the large individual differences in the dosage of Epo as well as the great individual variation in values of ERI. In the current study, the differences between the ERI individual values were high and weekly Epo dose for individual patients is widely varied from month to other because of continuous individualized adjustment of Epo doses according to Hgb concentration. The average weekly dose of Epo ranged from 55 to $98.3 \mathrm{U} / \mathrm{kg}$. It was evident that different patients required different Epo dosage for the maintenance of target $\mathrm{Hgb}$ level, that is consistent with numerous studies which included thousands of patients $[8,9,28,34]$.

Female gender was associated with a higher resistance to Epo in the studied patients. These results are consistent with data reported by other authors $[39,40,42]$ and might be explained by the difference seen in iron release from reticuloendothelial cells to the marrow for erythropoiesis in women versus men [43,44].

Age in the studied patients was inversely associated with resistance to Epo. Elderly patients received less Epo indicating that they did not experience functional iron deficiency as much as the younger patients. These results confirm the data of other authors [45]. However; some authors that older age was associated with higher resistance to Epo [40] as many elderly patients have low Hgb levels despite the high doses of ESA received, while others have found no association [46]. Further studies are needed to emphasize the true association between age and resistance to Epo.

Patients with a lower BMI, which indicated poor nutrition, had a higher ERI. This confirms results of Lopez-Gomez et al[40]. Since body weight is a part of the ERI definition, the results of BMI effects on ERI should be interpreted with caution.

The estimation equation for spKt/V based on the urea reduction ratio, the dialysis session length and fractional volume removal (weight loss divided by body weight). Kt, the top part of the fraction, is clearance multiplied by time, representing the volume of fluid completely cleared of urea during a single treatment $\mathrm{V}$, the bottom part of the fraction, is the volume of water a patient's body contains. Many studies confirmed the idea of association of well removal of uremic inhibitors of erythropoiesis through adequate dialysis dose and getting the target responsiveness to the Epo treatment suggesting that the more inflamed patients could have a lower $\mathrm{Kt} / \mathrm{V}$ because of difficulties in performing HD [47,48]. However, our finding in the studied patients was that increased dialysis dose $(\mathrm{Kt} / \mathrm{V})$ is associated with higher ERI. This may be explained as a delayed hemolysis or severe changes of the erythrocyte morphology occurred after prolonged extracorporeal circulation [49]. In agreement with our study, Lopez-Gomez et al [40] reported positive association of spKt/V and ERI but failed to find a statistical significance. Carefully designed studies are needed to further evaluate this association.

Comorbidities are thought to increase inflammatory state and hence associated with poor response to Epo [50,51]. The current study did not demonstrate a link between presence of hypertension, diabetes mellitus, congestive heart failure and ERI. This confirms previous result [39]. However, Lopez-Gomez et al. [40] found that patients with a history of heart failure had a higher ERI than patients without this antecedent. The current study failed to find such association perhaps due to relative small number of patients and limited ascertainment of these conditions. ERI values of anti-HCV-positive patients were lower than those of anti-HCV-negative ones; however, the difference wasn't statistically significant. This is in agreement with a recent study [52] which found that average required dose of Epo was lower in the anti-HCV-positive group than in the anti-HCVnegative group.

ACEIs thought to cause anemia through decreased production of RBCs. In addition, ACE inhibitors may impair erythropoiesis via either suppression of angiotensin-mediated Epo production or bone marrow response to Epo [53]. The relationship between the use of ACEI and ERI is still controversial, some investigations showed no relationship [54-56] while others [57,58] confirmed this study's finding and showed reduction in response to ESA. This study showed a positive significant association between statins use and ERI. This comes in agreement with several studies because of statins' pleiotropic properties that reduce inflammation[59-61]. By contrast, others [62] failed to show a statistical significant decrease in the CRP levels, suggesting a mechanism other than decrease in inflammation for the reduction of ERI.

Previous studies have shown that inflammation is one factor that reduces the response to Epo $[6,50,63,64]$. In addition, nutritional status plays a fundamental role in the clinical course of HD patients 
because it is closely related to inflammation through common mediators such as IL-6 or TNF- $\alpha[65,66]$. Therefore, albumin level could be considered a marker of nutritional status as well as inflammation. Malnutrition and inflammation can cause hypoalbuminemia and also suppress erythropoeisis since the elevated levels of cytokines particularly IL-1, mediates acute phase response, enhances CRP production and reduces albumin level and transferrin synthesis [19]. Low level of transferrin prevents transportation of iron to the hematopoietic sites and leads to suppression of Hgb synthesis as well as hyporesponsiveness to ESA [41]. Accordingly, this study pointed out that CRP was a significant independent predictor of response to Epo. In addition, the intensity of the response to Epo was inversely related to albumin concentration $(P<0.001)$. This finding coincides with other studies [38-40] .

Iron deficiency is an important cause of resistance to treatment with Epo in HD patients [18,67]. Possible causes for iron deficiency include occult gastrointestinal losses, blood losses due to residual blood in the dialyzer lines, the use of catheters for vascular access, routine laboratory tests and possible functional iron deficiency. This study found a significant negative relationship between transferrin saturation and ERI. In addition, patients with transferrin saturation below $20 \%$ had higher ERI values confirming that functional iron deficiency can be a substantial cause of Epo resistance. Furthermore, patients with transferrin saturation above $40 \%$ had lower ERI values suggesting that the appropriate levels of functional iron could enhance Epo response and that the ideal saturation level in such patients should be at least more than $20 \%$ as recommended by (KDOQI) guideline. In contrast, in studied patients, no relationship was found between serum ferritin and ERI. This matches the DRIVE study which reported that ferritin level is not a good marker to assess iron requirements [68]. In another study compared intravenous iron administration to no iron use in HD patients treated with Epo, an increase in Hgb occurred despite substantially elevated ferritin levels and iron stores markers was found to be of little value to guide iron management in HD patients [69].

Consistent with previous studies that included large samples [38,39,70], the current study found that hyperparathyroidism is directly associated with ESA hyporesponsiveness. It is evident that hyperparathyroidism diminishes endogenous Epo synthesis, reduces bone marrow erythroid progenitors, and shortens erythrocyte survival [71]. The higher iPTH suppressed the calcitriol receptor activity on the red cell surface, resulting in the deficiency of active vitamin D leading to the reduced releasing of endogenous Epo, reducing the sensitivity of peripheral tissue towards Epo, thus resulting in the Epo resistance.[72] In addition, hyperparathyroidism affected indirectly Epo response through the association of renal osteodystrophy with bone marrow fibrosis [73], that is confirmed by the restored bone marrow space as well as concomitant rise of serum Epo concentrations after parathyroidectomy [74].

It was evident that patients with lower serum total cholesterol level are likely to have a poorer nutritional status and possibly a greater likelihood of inflammation[75,76]. In the present study, both serum total cholesterol and triglycerides correlated inversely with ERI; however, no significant associations were found.

This study has several points of strength; the study was one year follow up study period to asses HD patients' responsiveness to Epo, which is higher than in most other studies $[17,28,77]$ In addition, a variety of biochemical markers and co-medication use that can affect ERI were analyzed. Furthermore, all laboratory data obtained from a single center which ensuring uniformity of laboratory measurements. However, several limitations should be noted. This study was not designed to investigate the influence of the route of administration. Compared to the intravenous route, subcutaneous administration of Epo requires lower doses [78]. Therefore, present results may have been skewed by the route of Epo administration. Also, the compliance with the prescribed medications, including statins and ACEI/ARBs, that were used as covariates in this study, were based only on self-report with no information on the actual compliance. Sample size in the current study was relative small, so further studies are required to be performed on large sample population in order to implement our findings as guidelines in management of anemia in Egyptian HD patients. This study didn't include patients with well-known causes of anemia such as hemorrhage, surgery, chronic infections and cancer diseases and conducted on relative stable HD patients not on incident ones. Therefore, the results can't be generalized [79].

\section{Conclusions}

Research conducted in this paper confirmed that achievement and maintenance of target Hgb level 10-12 $\mathrm{g} / \mathrm{dl}$ in HD patients necessitate different doses of ESA, as well as continuous adjustment of the dosage. It has been shown that there are significant individual differences in the response to the treatment with Epo, which was estimated using ERI, whereas serum albumin and CRP levels are the strongest significant factors associated with ERI. Therefore, it is necessary to continuously implement prevention and treatment of persistent co-morbid conditions that may occur in patients with CKD, in particular those that contribute to the occurrence of malnutrition and inflammation. These measures will lead to improving the management of anemia which has a significant impact on quality of life, morbidity, hospitalization and survival of patients. 


\section{Acknowledgements}

The authors would like to thank Dr. Mona A. Badr and Dr. Rehab F. Elzayat, doctors of dialysis ward of Nephrology Hospital of the Armed Forces Medical Center at Maadi; Cairo, Egypt, for their help in collecting data for this work.

[1]. Eschbach JW. The anemia of chronic renal failure: Pathophysiology and the effects of recombinant erythropoietin. Kidney Int, 1989; 35(1): 134-48.

[2]. Delano BG. Improvements in quality of life following treatment with r-HuEPO in anemic hemodialysis patients. Am J Kidney Dis, 1989; 14(2 Suppl 1): 14-8.

[3]. Kidney Disease: Improving Global Outcomes (KDIGO) Anemia Work Group. KDIGO Clinical Practice Guideline for Anemia in Chronic Kidney Disease. Kidney Int Suppl, 2012; 2(4): 279-335.

[4]. KDOQI Clinical Practice Guideline. KDOQI Clinical Practice Guideline and Clinical Practice Recomendations For Anemia in Chronic Kidney Disease: 2007 update of hemoglobin target. Am J Kidney Dis, 2007; 50: 471-530.

[5]. Macdougall IC. Poor response to erythropoietin: practical guidelines on investigation and management. Nephrol Dial Transplant, 1995; 10(5): 607-14

[6]. Gunnell J, Yeun JY, Depner TA, Kaysen GA. Acute-phase response predicts erythropoietin resistance in hemodialysis and peritoneal dialysis patients. Am J Kidney Dis, 1999; 33(1): 63-72.

[7]. Eschbach JW, Egrie JC, Downing MR, Browne JK, Adamson JW. Correction of the Anemia of End-Stage Renal Disease with Recombinant Human Erythropoietin. N Engl J Med, 1987; 316(2): 73-8.

[8]. Fishbane S, Berns JSJ. Hemoglobin cycling in hemodialysis patients treated with recombinant human erythropoietin. Kidney Int, 2005; 68(3): 1337-43.

[9]. Ebben JP, Gilbertson DT, Foley RN, Collins AJ. Hemoglobin level variability: associations with comorbidity, intercurrent events, and hospitalizations. Clin J Am Soc Nephrol, 2006; 1(6): 1205-10.

[10]. Walker R, Pussell BA. Fluctuations in haemoglobin levels in haemodialysis, pre-dialysis and peritoneal dialysis patients receiving epoetin alpha or darbepoetin alpha: Original Article. Nephrology, 2009; 14(7): 689-95.

[11]. Meester J De, Maes B, Vriese A De, Moor B De, Donck J, Helbert M i wsp. Fluctuations of Haemoglobinaemia in Chronic Haemodialysis Patients. Acta Clin Belg, 2011; 66(2): 123-8.

[12]. Levin A. Understanding recent haemoglobin trials in CKD: methods and lesson learned from CREATE and CHOIR. Nephrol Dial Transplant, 2006; 22(2): 309-12.

[13]. Locatelli F, Pisoni RL, Combe C, Bommer J, Andreucci VE, Piera L i wsp. Anaemia in haemodialysis patients of five European countries: association with morbidity and mortality in the Dialysis Outcomes and Practice Patterns Study (DOPPS). Nephrol Dial Transplant, 2004; 19(1): 121-32.

[14]. Zhang Y, Thamer M, Stefanik K, Kaufman J, Cotter DJ. Epoetin requirements predict mortality in hemodialysis patients. Am J Kidney Dis, 2004; 44(5): 866-76.

[15]. Ishigami J, Onishi T, Shikuma S, Akita W, Mori Y, Asai T i wsp. The impact of hyporesponsiveness to erythropoietin-stimulating agents on time-dependent mortality risk among CKD stage 5D patients: a single-center cohort study. Clin Exp Nephrol, 2013; 17(1): 106-14.

[16]. Kilpatrick RD, Critchlow CW, Fishbane S, Besarab A, Stehman-Breen C, Krishnan M i wsp. Greater Epoetin alfa Responsiveness Is Associated With Improved Survival in Hemodialysis Patients. Clin J Am Soc Nephrol, 2008; 3(4): 1077-83.

[17]. Regidor DL. Associations between Changes in Hemoglobin and Administered Erythropoiesis-Stimulating Agent and Survival in Hemodialysis Patients. J Am Soc Nephrol, 2006; 17(4): 1181-91.

[18]. Besarab a, Amin N, Ahsan M, Vogel SE, Zazuwa G, Frinak S i wsp. Optimization of epoetin therapy with intravenous iron therapy in hemodialysis patients. J Am Soc Nephrol, 2000; 11(3): 530-8.

[19]. Agarwal R, Davis JL, Smith L. Serum albumin is strongly associated with erythropoietin sensitivity in hemodialysis patients. Clin J Am Soc Nephrol, 2008; 3(1): 98-104.

[20]. Madore F, Lowrie EG, Brugnara C, Lew NL, Lazarus JM, Bridges K i wsp. Anemia in hemodialysis patients: variables affecting this outcome predictor. J Am Soc Nephrol, 1997; 8(12): 1921-9.

[21]. Sudhaker Rao D, Mei-shu Shih RM. Effect of serum parathyroid hormone and bone marrow fibrosis on the response to erythropoietin in uremia. N Engl J Med, 1993(328): 171-5.

[22]. Ifudu O, Feldman J, Friedman E a. The intensity of hemodialysis and the response to erythropoietin in patients with end-stage renal disease. N Engl J Med, 1996; 334(7): 420-5.

[23]. Macdougall IC, Gray SJ, Elston O, Breen C, Jenkins B, Browne J i wsp. Pharmacokinetics of novel erythropoiesis stimulating protein compared with epoetin alfa in dialysis patients. J Am Soc Nephrol, 1999; 10(11): 2392-5.

[24]. Locatelli F, Olivares J, Walker R, Wilkie M, Jenkins B, Dewey C i wsp. Novel erythropoiesis stimulating protein for treatment of anemia in chronic renal insufficiency. Kidney Int, 2001; 60(2): 741-7.

[25]. Daugirdas JT. Second generation logarithmic estimates of single-pool variable volume Kt/V: an analysis of error. J Am Soc Nephrol, 1993; 4(5): 1205-13.

[26]. Kaysen GA, Müller HG, Ding J, Chertow GM. Challenging the Validity of the EPO Index. Am J Kidney Dis, 2006; 47(1): 166.e1166.e13.

[27]. Lopez-Gomez JM. Presence of a Failed Kidney Transplant in Patients Who Are on Hemodialysis Is Associated with Chronic Inflammatory State and Erythropoietin Resistance. J Am Soc Nephrol, 2004; 15(9): 2494-501.

[28]. Gilbertson DT, Peng Y, Bradbury B, Ebben JP, Collins AJ. Hemoglobin level variability: Anemia management among variability groups. Am J Nephrol, 2009; 30(6): 491-8.

[29]. Kainz A, Mayer B, Kramar R, Oberbauer R. Association of ESA hypo-responsiveness and haemoglobin variability with mortality in haemodialysis patients. Nephrol Dial Transplant, 2010; 25(11): 3701-6.

[30]. Fukuma S, Yamaguchi T, Hashimoto S, Nakai S, Iseki K, Tsubakihara Y i wsp. Erythropoiesis-Stimulating Agent Responsiveness and Mortality in Hemodialysis Patients: Results from a Cohort Study From the Dialysis Registry in Japan. Am J Kidney Dis, 2012; 59(1): 108-16.

[31]. Portolés J, López-Gómez JM, Aljama P. A prospective multicentre study of the role of anaemia as a risk factor in haemodialysis 
patients: The MAR Study. Nephrol Dial Transplant, 2007; 22(2): 500-7.

[32]. Phrommintikul A, Haas SJ, Elsik M, Krum H. Mortality and target haemoglobin concentrations in anaemic patients with chronic kidney disease treated with erythropoietin: a meta-analysis. Lancet, 2007; 369(9559): 381-8.

[33]. Mitchell P, Med M, Wriedt C, Graves S, Phil D, Staples MP i wsp. New England Journal. Sci York, $2009: 557-68$.

[34]. Collins AJ, Brenner RM, Ofman JJ, Chi EM, Stuccio-White N, Krishnan M i wsp. Epoetin Alfa Use in Patients With ESRD: An Analysis of Recent US Prescribing Patterns and Hemoglobin Outcomes. Am J Kidney Dis, 2005; 46(3): 481-8.

[35]. Boudville NC, Djurdjev O, Macdougall IC, Francisco ALM de, Deray G, Besarab A i wsp. Hemoglobin Variability in Nondialysis Chronic Kidney Disease: Examining the Association with Mortality. Clin J Am Soc Nephrol, 2009; 4(7): $1176-82$.

[36]. U.S. Food and Drug Administration. FDA Drug Safety Communication: Modified dosing recommendations to improve the safe use of Erythropoiesis-Stimulating Agents (ESAs) in chronic kidney disease, 2011: 1-5.

[37]. Li S, Foley RN, Gilbertson DT, Liu J, Collins AJ. Clinical factors associated with achieving K/DOQI hemoglobin targets in hemodialysis patients. Int Urol Nephrol, 2003; 35(3): 399-405.

[38]. Kalantar-Zadeh K, Lee GH, Miller JE, Streja E, Jing J, Robertson JA i wsp. Predictors of Hyporesponsiveness to ErythropoiesisStimulating Agents in Hemodialysis Patients. Am J Kidney Dis, 2009; 53(5): 823-34.

[39]. Mallick S, Rafiroiu A, Kanthety R, Iqbal S, Malik R, Rahman M. Factors predicting erythropoietin resistance among maintenance hemodialysis patients. Blood Purif, 2012; 33(4): 238-44.

[40]. López-Gómez JM, Portolés JM, Aljama P. Factors that condition the response to erythropoietin in patients on hemodialysis and their relation to mortality. Kidney Int Suppl, 2008; 74(111): S75-81.

[41]. Rattanasompattikul M, Molnar MZ, Zaritsky JJ, Hatamizadeh P, Jing J, Norris KC i wsp. Association of malnutrition-inflammation complex and responsiveness to erythropoiesis-stimulating agents in long-term hemodialysis patients. Nephrol Dial Transplant, $2013 ; 28(7): 1936-45$.

[42]. Ifudu O, Uribarri J, Rajwani I, Vlacich V, Reydel K, Delosreyes G i wsp. Gender modulates responsiveness to recombinant erythropoietin. Am J Kidney Dis, 2001; 38(3): 518-22.

[43]. Deiss A. Iron metabolism in reticuloendothelial cells. Semin Hematol, 1983; 20(2): 81-90.

[44]. T Uchida, T Akitsuki, H Kimura et al. Relationship among plasma iron, plasma iron turnover, and reticuloendothelial iron release. Blood, 1983; 61(4).

[45]. Nicholas JCB. A study of the response of elderly patients with end-stage renal disease to epoetin alfa or beta. Drugs Aging, 2004; 21(3): 187-201.

[46]. Bamgbola OF, Kaskel FJ, Coco M. Analyses of age, gender and other risk factors of erythropoietin resistance in pediatric and adult dialysis cohorts. Pediatr Nephrol, 2009; 24(3): 571-9.

[47]. Locatelli F, Vecchio L Del. Dialysis adequacy and response to erythropoietic agents: what is the evidence base? Nephrol Dial Transplant, 2003; 18 Suppl 8: viii29-35.

[48]. Movilli E, Cancarini GC, Zani R, Camerini C, Sandrini M, Maiorca R. Adequacy of dialysis reduces the doses of recombinant erythropoietin independently from the use of biocompatible membranes in haemodialysis patients. Nephrol Dial Transplant, 2001; 16(1): 111-4.

[49]. Polaschegg H-D. Red blood cell damage from extracorporeal circulation in hemodialysis. Semin Dial, 2009; 22(5): 524-31

[50]. Locatelli F, Andrulli S, Memoli B, Maffei C, Vecchio L Del, Aterini S i wsp. Nutritional-inflammation status and resistance to erythropoietin therapy in haemodialysis patients. Nephrol Dial Transplant, 2006; 21(4): 991-8.

[51]. Abe M, Okada K, Maruyama T, Maruyama N, Matsumoto K, Soma M. Relationship between erythropoietin responsiveness, insulin resistance, and malnutrition-inflammation-atherosclerosis (MIA) syndrome in hemodialysis patients with diabetes. Int $\mathrm{J}$ Artif Organs, 2011; 34(1): 16-25.

[52]. Saifan C, El-Charabaty E, Kleiner M, El-Sayegh S. Effect of hepatitis C virus infection on erythropoiesis in patients on hemodialysis. Int J Nephrol Renovasc Dis, 2013; 6: 121-4.

[53]. Vlahakos D V, Marathias KP, Madias NE. The Role of the Renin-Angiotensin System in the Regulation of Erythropoiesis. Am J Kidney Dis, 2010; 56(3): 558-65.

[54]. Saudan P, Halabi G, Perneger T, Wasserfallen J-B, Wauters J-P, Martin P-Y. ACE inhibitors or angiotensin II receptor blockers in dialysed patients and erythropoietin resistance. J Nephrol, 2006; 19(1): 91-6.

[55]. Abu-alfa AK, Cruz D, Perazella MA, Mahnensmith RL, Simon D, Bia MJ. ACE Inhibitors Do Not Induce Recombinant Human Erythropoietin Resistance in Hemodialysis Patients, 2000; 35(6): 1076-82.

[56]. Hayashi K, Hasegawa K, Kobayashi S. Effects of angiotensin-converting enzyme inhibitors on the treatment of anemia with erythropoietin. Kidney Int, 2001; 60(5): 1910-6.

[57]. Qureshi IZ, Abid K, Ambreen F, Qureshi AL. Angiotensin converting enzyme inhibitors impair recombinant human erythropoietin induced erythropoiesis in patients with chronic renal failure. Saudi Med, 2007; 28(2): 193-6.

[58]. Albitar S, Genin R, Fen-Chong M, Serveaux MO, Bourgeon B. High dose enalapril impairs the response to erythropoietin treatment in haemodialysis patients. Nephrol Dial Transplant, 1998; 13(5): 1206-10.

[59]. Chiang C-K, Yang S-Y, Peng Y-S, Hsu S-P, Pai M-F, Huang J-W i wsp. Atorvastatin Increases Erythropoietin-Stimulating Agent Hyporesponsiveness in Maintenance Hemodialysis Patients: Role of Anti-Inflammation Effects. Am J Nephrol, 2009; 29(5): 392-7.

[60]. Sirken G, Kung SC, Raja R. Decreased erythropoietin requirements in maintenance hemodialysis patients with statin therapy, 2003; 2003/08/16(4): 422-5.

[61]. Mohamady U. Impact of Atorvastatin therapy on Erythropoietin dose in anemic chronic Haemodialysis Patients. Int J Acad Res, 2013; 5(6): 78-89.

[62]. Bonnet J, McPherson R, Tedgui A, Simoneau D, Nozza A, Martineau P i wsp. Comparative effects of 10-mg versus 80-mg Atorvastatin on high-sensitivity C-reactive protein in patients with stable coronary artery disease: Results of the CAP (Comparative Atorvastatin Pleiotropic effects) study. Clin Ther, 2008; 30(12): 2298-313.

[63]. Bradbury BD, Critchlow CW, Weir MR, Stewart R, Krishnan M, Hakim RH. Impact of elevated C-reactive protein levels on erythropoiesis- stimulating agent (ESA) dose and responsiveness in hemodialysis patients. Nephrol Dial Transplant, 2009; 24(3): 919-25.

[64]. Lazarevic T, Stojimirovic B, Poskurica M, Lazarevic M, Mitrovic N, Stolic R. Chronic inflammation, oxidative stress and effects of erythropoetin in end-stage renal disease patients. Med Pregl, 2007; 60(2): 109-13.

[65]. Baldini G, Bagry H, Aprikian A, Carli F. Inflammation in End-stage Renal Disease: Sources, Consequences, and Therapy. Anesthesiology, 2009; 110(5): 1139-57.

[66]. Pecoits-Filho R, Lindholm B, Axelsson J, Stenvinkel P. Update on interleukin-6 and its role in chronic renal failure. Nephrol Dial Transplant, 2003; 18(6): 1042-5.

[67]. Tessitore N, Solero GP, Lippi G, Bassi A, Faccini GB, Bedogna V i wsp. The role of iron status markers in predicting response to 
intravenous iron in haemodialysis patients on maintenance erythropoietin. Nephrol Dial Transplant, 2001; 16(7): 1416-23.

[68]. Coyne DW, Kapoian T, Suki W, Al E, Singh AK, Moran JE i wsp. Ferric gluconate is highly efficacious in anemic hemodialysis patients with high serum ferritin and low transferrin saturation: results of the Dialysis Patients' Response to IV Iron with Elevated Ferritin (DRIVE) Study. J Am Soc Nephrol, 2007; 18(3): 975-84.

[69]. Singh AK, Coyne DW, Shapiro W, Rizkala AR, the DRIVE Study Group. Predictors of the response to treatment in anemic hemodialysis patients with high serum ferritin and low transferrin saturation. Kidney Int, 2007; 71(11): $1163-71$.

[70]. Kalantar-zadeh K, Lee GH, Miller JE, Streja E, Jing J, Robertson J a i wsp. Predictors of Hyporesponsiveness to ErythropoiesisStimulating Agents in Hemodialysis Patients, 2010; 53(5): 823-34.

[71]. Brancaccio D. Hyperparathyroidism and Anemia in Uremic Subjects: A Combined Therapeutic Approach. J Am Soc Nephrol, 2004; 15(90010): 21S-24.

[72]. Battistella M, Richardson RMA, Bargman JM, Chan CT. Improved parathyroid hormone control by cinacalcet is associated with reduction in darbepoetin requirement in patients with end-stage renal disease. Clin Nephrol, 2011; 76(2): 99-103.

[73]. Khoury N, Chang J, Gru AA, Whyte MP. Resorptive hypercalcemia in post-essential thrombocythemia myelofibrosis: treatment with denosumab. J Clin Endocrinol Metab, 2012; 97(9): 3051-5.

[74]. Gallieni M, Corsi C, Brancaccio D. Hyperparathyroidism and Anemia in Renal Failure. Am J Nephrol, 2000; 20(2): 89-96.

[75]. Kalantar-Zadeh K, McAllister CJ, Lehn RS, Lee GH, Nissenson AR, Kopple JD. Effect of malnutrition-inflammation complex syndrome on EPO hyporesponsiveness in maintenance hemodialysis patients. Am J Kidney Dis, 2003; 42(4): 761-73.

[76]. Liu Y, Coresh J, Eustace J, Longenecker J, Jaar B, Fink N i wsp. Association Between Cholesterol Level and Mortality in Dialysis Patients. Jama, 2004; 291(4): 451-9.

[77]. Streja E, Kovesdy CP, Greenland S, Kopple JD, McAllister CJ, Nissenson AR i wsp. Erythropoietin, Iron Depletion, and Relative Thrombocytosis: A Possible Explanation for Hemoglobin-Survival Paradox in Hemodialysis. Am J Kidney Dis, 2008; 52(4): 72736.

[78]. Patel T, Hirter A, Kaufman J, Keithi-Reddy SR, Reda D, Singh A. Route of epoetin administration influences hemoglobin variability in hemodialysis patients. Am J Nephrol, 2009; 29(6): 532-7.

[79]. Jager KJ, Stel VS, Zoccali C, Wanner C, Dekker FW. The issue of studying the effect of interventions in renal replacement therapy to what extent may we be deceived by selection and competing risk? Nephrol Dial Transplant, 2010; 25(12): 3836-9. 